\title{
Discretionary Grants and Distributive Politics: Evidence from Spain
}

\author{
Elena Jarocinska ${ }^{1,2} \mathbb{D}$
}

Accepted: 29 January 2022 / Published online: 3 March 2022

(C) The Author(s) 2022

\begin{abstract}
We study empirically whether the allocation of discretionary grants across Spanish regions is related to the number of swing voters and loyal voters of the ruling party. We estimate the number of swing and loyal voters from survey data. When estimating the number of swing voters, we account in a novel way for the two-dimensional ideological space and multiparty competition. We find that regions with more loyal voters of the ruling party received more grants per capita. Partisan alignment of regional governments also matters over a part of the studied period since the regions where the socialist party of the central government was a member of the regional government received more grants.
\end{abstract}

Keywords Distributive politics · Discretionary grants $\cdot$ Swing voters $\cdot$ Loyal voters · Partisan alignment $\cdot$ Spain

JEL classifications $\mathrm{H} 5 \cdot \mathrm{H} 77 \cdot \mathrm{O} 1$

\section{Introduction}

Do political considerations affect the allocation of public funds across geographic regions and, if yes, how? Dominant theories of distributive politics predict that politicians favor either loyal voters (Cox and McCubbins 1986) or swing voters (Linbeck and Weibull 1987; Dixit and Londregan 1996). We test these theories using Spanish data. We study how the allocation of discretionary grants across Spanish regions relates to the number of loyal voters and swing voters in the region.

To construct our proxies for the number of loyal and swing voters, we use data from sixteen public opinion surveys and estimate the evolution of voters' ideological

Elena Jarocinska

elena.jarocinska@gmail.com

1 EBS Universität für Wirtschaft und Recht, Rheingaustraße 1, 65375 Oestrich-Winkel, Germany

2 CASE - Center for Social and Economic Research, Warsaw, Poland 
preferences over time in each region. The fact that we proxy for the number of loyal and swing voters using information on ideological preferences, and not on actual votes, is a new and important feature of our study. Most empirical studies of distributive politics use proxies based on actual votes (e.g., Wright 1974; Levitt and Potterba 1999; Case 2001; Stromberg 2004 and others). However, as these studies acknowledge, proxies based on actual votes have two shortcomings. First, they are valid only under restrictive assumptions: single peaked and symmetric distribution of preferences, and two-party competition. Second, in the models of distributive politics, voting decisions are-by assumption-endogenous to the distribution of public funds. This endogeneity complicates the interpretation of regressions that include proxies based on actual votes. Proxies based on survey data, that we use, while not perfect, are arguably more exogenous (see Larcinese et al. 2012).

Proxying swing and loyal voters using survey data is important in the Spanish case. First, we find that the distributions of political preferences within Spanish regions are likely to be multi-peaked and asymmetric, so the assumptions of single-peakedness and symmetry would have been inappropriate. Second, in some Spanish regions regional parties play an important role in addition to the two main countrywide parties (Colomer 2003), so the assumption of two-party competition would have been inappropriate as well. Third, our survey data allow us to take into account a distinguishing feature of Spanish politics: in some regions the ideological space is two-dimensional. In addition to the standard left-right dimension, in these regions there is a prominent second ideological dimension related to the support for the regional/national aspirations (Colomer 2003). To our knowledge, our paper is the first one in the literature to estimate the number of swing voters from survey data in a two-dimensional ideological space, taking into account more than two major parties.

Is it reasonable to assume that politicians use swing and loyal voters measures that we construct when making their decisions? First, we know that politicians extensively use surveys (as well as focus groups and meetings with important stakeholders) to learn about the public opinion. These surveys and focus groups are frequent and custom-made for the salient issues. However, they are not publicly available. The measures we construct from publicly available surveys aim to approximate as well as possible the sophisticated knowledge of the public opinion that the politicians have. Second, we do not think that Spanish politicians literally base their decisions on our (or similar) constructed measures of swing and loyal voters. Instead, we think that our constructed measures are a simple (and probably imperfect) way to capture the politicians' complex decision making process, based on their sophisticated knowledge of the public opinion.

Our empirical analysis proceeds in two steps. First, we compute our proxies for the number of loyal and swing voters. Second, we regress discretionary grants on these proxies and other controls in a panel of 15 regions observed annually between 1987 and 2007.

We compute the following proxies for the number of loyal and swing voters. We use survey data where respondents locate themselves as well as political parties on the ideological scale. Our proxy for the number of loyal voters of the ruling party is the share of respondents who locate themselves much closer to the ruling party 
than to any other party. We experiment with different quantitative definitions of "much closer." Our proxies for the number of swing voters are obtained using two approaches. In the first approach we compute the share of respondents who locate themselves at a similar distance to the ruling party and to another party. We experiment with different quantitative definitions of "similar distance." In the second approach we estimate densities at the critical value or "cutpoint" that divides the voters of the ruling party from the voters of another party. The higher the density at the cutpoint, the more swing voters there are in a region (Dixit and Londregan 1996).

In the second stage of the analysis, we run a panel regression of discretionary grants per capita on the proxies for swing and loyal voters, as well as other controls. The discretionary grants that we use as the left-hand side variable are appropriate for testing theories of distributive politics, because their allocation is controlled by the federal government and no prescribed formula for their allocation exists. The political determinants of a subset of these grants have been studied only by SimonCosano et al. (2013).

We find robust evidence for the loyal voter hypothesis (the hypothesis that the ruling party favors loyal voters). The proxies for the number of loyal voters enter significantly into the regressions for the allocation of discretionary grants, and the magnitude of the effect is large. We do not find robust evidence for the swing voter hypothesis. In addition, we find support for the partisan alignment hypothesis during the years of the PSOE rule (the hypothesis that grants are biased in favor of the regions where there is partisan alignment between the central and regional layers of government).

To our knowledge, there are only three previous studies that use survey data for testing theories of distributive politics. Larcinese et al. (2012) use survey data from exit polls in their study of the allocation of federal spending across US states. They do not find evidence for the strategic use of federal spending by the incumbent party. Dahlberg and Johansson (2002) and Johansson (2003) use the Swedish election study to construct a proxy for the number of swing voters and find support for the swing voter hypothesis in the allocation of Swedish ecological grants.

Larcinese et al. (2012) also discuss extensively the possible endogeneity of voters' ideological positions to the distribution of public funds (Larcinese et al. 2012). In particular, they argue that first, ideological preferences evolve slowly over time, while the empirical analysis typically focuses on short-term changes. Second, when ideological preferences do slowly change over time, none of the factors that lead to those changes (e.g., major changes in the parties' issue positions) are clearly related to the dependent variable of interest. ${ }^{1}$ Larcinese et al. (2012) conclude that the use of survey data, even if not a definitive solution to the endogeneity problem, is a step in the right direction.

We contribute to the literature on the Spanish distributive politics in two principal ways. First, we estimate the distributions of ideological preferences in Spanish

\footnotetext{
${ }^{1}$ Larcinese et al. (2012) mention one caveat, namely that factors influencing the evolution of ideological preferences might be indirectly related to the distribution of discretionary grants.
} 
regions. The estimation of these distributions is nontrivial because each respondent perceives the scale of the ideological space differently. We use the procedure of Aldrich and McKelvey to deal with this problem (Aldrich and McKelvey 1977; Poole et al. 2011). We find that the distributions of ideological preferences appear asymmetric, multi-peaked and quite stable over time. Second, we complement the existing studies by providing evidence that the loyal voter hypothesis can explain the allocation of public monies in Spain. Our study is complementary to the literature since we use a very different empirical strategy than the previous studies of Spain. ${ }^{2}$

The paper is organized as follows. Section "Hypotheses and their Previous Empirical Tests" discusses hypotheses of distributive politics and relates our paper to the existing literature. Section "Proxies for the Number of Loyal and Swing Voters" explains our proxies for the number of loyal and swing voters based on survey data. Section "Empirical Analysis of the Determinants of Discretionary Grants" presents regression results. Section "Conclusion" concludes.

\section{Hypotheses and their Previous Empirical Tests}

Models of distributive politics assume that parties facing an election promise transfers that benefit particular groups of voters (Cox and McCubbins 1986; Linbeck and Weibull 1987; Snyder 1989; Dixit and Londregan 1995, 1996). Two main hypotheses emerge from the analysis of these models. The first hypothesis is that parties favor loyal voters. The second hypothesis is that parties favor swing voters. These two hypotheses are not mutually exclusive, as parties might favor both loyal and swing voters at the expense of voters loyal to political opponents.

The intuition behind the loyal voter hypothesis is the following. Transfers to particular groups of voters are modeled as investments with uncertain payoffs in votes. Investing in loyal voters is assumed to be less risky than investing in swing voters, and parties are assumed to be risk averse. As a result, parties often prefer investing in loyal voters. For a formal model supporting the loyal voter hypothesis, see Cox and McCubbins (1986).

The intuition behind the swing voter hypothesis is the following. Voters are assumed to have ideological preferences over parties, but they also care about material benefits. In each region there is a distribution of ideological preferences and given a certain level of regional transfers, there is a critical value or "cutpoint" that divides voters between party A and party B. By spending public monies, the ruling party is able to shift the cutpoint to increase its share of the votes. The ruling party will then allocate more spending to regions where the density at the cutpoint is higher, i.e., to regions with a higher number of swing voters. For a formal model supporting the swing voter hypothesis, see Linbeck and Weibull (1987), and Dixit and Londregan (1996).

Many studies test these two hypotheses of distributive politics and the findings vary across countries. Let us discuss those studies that are most related to ours.

${ }^{2}$ We discuss the literature on distributive politics in Spain in detail in the next section. 
Several studies find support for the loyal voter hypothesis. Levitt and Snyder (1995) and Larcinese et al. (2006), studying different samples, show that US states that supported the incumbent president in past presidential elections tend to receive more federal spending. Jarocinska (2010) finds that the regions with higher shares of pro-incumbent vote were rewarded with higher transfers in Russia.

Dahlberg and Johansson (2002) and Johansson (2003) find support for the swing hypothesis in the allocation of ecological grants and intergovernmental grants, respectively, in Sweden. Similar to us, they proxy for the number of swing voters using the density at the cutpoint estimated from survey data. Apart from studying a different country, there are two methodological differences between their work and ours. First, the surveys they use do not include questions about the ideological positions of parties. Consequently, the location of the cutpoint is not pinned down and they need to construct the cutpoint indirectly. By contrast, a unique feature of our surveys is that they do include questions about the ideological positions of parties. Consequently, in our survey data the cutpoints are pinned down. Second, they study a one-dimensional ideological space, while we have to take into account that in some Spanish regions the ideological space is two-dimensional.

Larcinese et al. (2012) use survey data from US exit polls and find no evidence that states with many swing voters receive more federal funds. They measure the number of swing voters as the share of independents from the following question: "Do you normally think of yourself as a Democrat, Republican, Independent?" Since the surveys that we use do not include an analogous question for Spain, we resort to different methods of estimating the share of swing voters.

Many studies use the closeness of the last election as a proxy for the number of swing voters. See, e.g., Case (2001), Schady (2000), and Veiga and Pinho (2007). It is well known (and acknowledged in this literature) that the closeness proxy is only valid when the distribution of ideological preferences is symmetric and single peaked. If not, it is easy to construct counterexamples. Imagine a constituency that is evenly split, where half of the voters are at one extreme of the ideological spectrum and the other half are at the other extreme. In this constituency, elections will be close, even though there are no swing voters. Johansson (2003) compares the results obtained using the closeness of an election as a proxy with the results obtained using the density at the cutpoint as a proxy. She finds that the relation between the number of swing voters and intergovernmental grants in Sweden is only significant when the density at the cutpoint proxy is used, and it becomes insignificant when the closeness proxy is used. This shows that the choice of the proxy might matter for the findings.

The closeness of an election in a region is not a good proxy for swing voters also when more than two parties compete. See Snyder (1990) for a discussion. With two parties, closeness is a relatively well defined notion, namely a race in district A is closer than in district B if the probability of either party winning is closer to $1 / 2$ in district A. However, with three of more relevant parties, closeness is, as Snyder puts it, a "slippery multidimensional creature." It is not clear which race is closer: the one with probabilities of winning $1 / 2,3 / 8$ and $1 / 8$ or the one with $1 / 2,1 / 4$ and $1 / 4$ ? 
An alternative way to proxy the number of swing voters based on vote shares in elections is proposed by Wright (1974). He purges the time trend from vote shares, relates the standard deviation of vote shares to the standard deviation of the underlying distribution of voters and, assuming normality, recovers the voter density at the cutpoint.

Studies on distributive politics in Spain can be classified into three groups by the administrative unit of analysis: regional, provincial and municipal. ${ }^{3}$ On the regional level, Simon-Cosano et al. (2013) studies earmarked grants that are spent on public investment in infrastructure (investment agreements). ${ }^{4}$ Their paper is different from ours in the empirical strategy as it uses vote-based proxies to test theories of distributive politics. They find support for the loyal hypothesis. In particular, they find that the levels of grants will be higher in those regions where the national incumbents have more loyal voters in previous election and have more seats in the parliament. In addition, national incumbents tend to allocate intergovernmental transfers where there are competitive regional elections (Simon-Cosano et al. 2013).

Castells and Solé-Ollé (2005) and Solé-Ollé (2013) analyze political factors in the distribution of public funds on a more disaggregated level: provinces. Both papers focus on the allocation of infrastructure investment. Castells and Solé-Ollé (2005) apply Wright's procedure to proxy the number of swing voters discussed above to Spanish data. They do not find a statistically significant effect of the number of swing voters based on their swing voter proxy. They do find, however, evidence of strategic allocation of funds in Spain. Namely, constituencies that are more "electorally productive" are favored with higher infrastructure investment. Their measure of electoral productivity captures, among others, the number of voters per one seat in the parliament. They measure electoral productivity at the level of electoral districts which coincide with the administrative provinces. In this paper, we do not control for electoral productivity because the grants that we study are only available at the level of regions (a higher administrative level) and electoral productivity has little variation at the level of regions.

Solé-Ollé (2013) extends the data to 2004 and controls in a systematic way for programmatic redistribution by taking into account several objective criteria underlying allocation of infrastructure investment. The main finding is that districts with more "Political power" receive more investments. These districts are those where the incumbents' vote margin of victory/defeat in the past election is low, where the marginal seat price is low and where there is partisan alignment between the executives at the central and regional layers of government.

Finally, Carrozzi and Repetto (2019) study Spanish municipalities using data from a fiscal stimulus program carried out in Spain between 2009 and 2011. They use within-city variation in the location of projects with both OLS and a regression

\footnotetext{
3 Span consists of three levels of administrative division. There are 17 regions or autonomous communities, 50 provinces and 8,118 municipalities in Spain.

4 Investment agreements (Convenios de Inversion in Spanish) is one subgroup of discretionary grants from the central government to regions. In our paper, we study total discretionary grants, which in addition to investment agreements also include a) programs of retraining and job creations and b) various social programs.
} 
discontinuity design. They do not find evidence that mayors use spending to favor areas of core support. Instead, investment goes disproportionately to low turnout areas, suggesting that politicians use funds to increase participation.

Another hypothesis, similar to the loyal voter hypothesis, suggests that partisan alignment of subnational governments may influence the allocation of transfers. Arulampalam et al. (2009) propose a model of center-state transfers predicting that grants are biased in favor of the regions ruled by the party that also rules the federal center. In these regions, the ruling party reaps the entire electoral benefit of any additional expenditure in the state and there is no leakage to the benefit of the other party. Testa et al. (2006), Solé-Ollé and Sorribas-Navarro (2008), and Arulampalam et al. (2009) find empirical support for the partisan alignment hypothesis in the USA, Spain and India, respectively. Following this literature, we also control for the partisan alignment of regional government in our regressions.

\section{Proxies for the Number of Loyal and Swing Voters}

This section explains how we construct proxies for the number of loyal and swing voters from survey data. First, we divide our regions into two groups that require different treatments. Second, we describe our survey data. Third, we explain how we construct proxies for the number of loyal voters. Fourth, we explain two approaches to compute proxies for the number of swing voters. Fifth, we describe the distributions of respondent preferences that underlie our proxies and are of independent interest.

Before proceeding, let us clarify our terminology. First, by "regions" we mean autonomous communities (communidad autonoma) of which there are seventeen in Spain. Second, by "ruling party" we mean the party that forms the central government and with which the prime minister is associated. In the period that we study, 1987-2007, the ruling party is unambiguously determined as there was never a "grand coalition" between the main parties: the PSOE and the PP. The PSOE was the ruling party from January 1986 to March 1996, then the PP from April 1996 to March 2004 and again the PSOE from April 2004 to December 2007.

\section{One- and Two-Dimensional Regions}

We divide the Spanish regions into two groups that differ in the number of ideological dimensions of political competition and in the number of main parties. We call the first group "one-dimensional regions" and the second group "two-dimensional regions." This division follows Colomer (2003).

The one-dimensional regions are characterized as follows. First, electoral competition in these regions takes place mainly on the ideological left-right dimension. Second, these regions have (imperfect) bi-party systems: the two major statewide parties, the socialist party PSOE and the conservative party PP, together account for over $80 \%$ of the vote. Colomer assigns eleven regions to this group: Andalusia, 
Principality of Asturias, Balearic Islands, Cantabria, Castile-La Mancha, Castile and León, Community of Madrid, Extremadura, La Rioja, Region of Murcia and Valencian Community.

The two-dimensional regions are characterized by strong regional/national identities. As a result, first, electoral competition in these regions has a prominent second dimension related to the support for the regional/national aspirations, in addition to the classical left-right dimension. We refer to this second ideological dimension as the centralist-nationalist dimension. Second, these regions have strong regional parties in addition to the statewide PSOE and PP. Colomer assigns six regions to this group: Aragon, Basque Country, Canary Islands, Catalonia, Galicia and Navarre.

In our analysis, we are forced to treat Aragon and the Canary Islands as onedimensional, because of the lack of data related to the second ideological dimension. Moreover, we exclude the Basque Country and Navarra from our analysis altogether, as these regions have a separate fiscal regime. ${ }^{5}$

As a result, we have thirteen regions that we treat as one-dimensional: the eleven regions of Colomer plus Aragon and the Canary Islands. We have two regions that we treat as two-dimensional: Catalonia and Galicia. To simplify our analysis, we only take into account one regional party in each region-the largest one. In Catalonia, the regional party that we take into account is Convergència i Unió (CIU). In Galicia, the regional party that we take into account is Coalición Galega (CG) in 1987 and Bloque Nacionalista Galego (BNG) in the remaining years.

\section{Survey Data}

We proxy the number of swing and loyal voters based on surveys where respondents report their own ideal points and their perceived locations of major parties in the ideological space. We use the answers to the following questions:

(1) In politics, people usually use terms "left" and "right." Please, identify yourself and the parties on the scale $1-10$, from left to right.

(2) With respect to the nationalist/regionalist sentiment, please locate yourself and the parties on the scale 1-10, where 1 means the minimum degree of Catalan (Galician) nationalism and 10 means the maximum degree of Catalan (Galician) nationalism. ${ }^{6}$

We use post-electoral surveys and public opinion surveys of political preferences conducted by the Centro de Investigaciones Sociológicas (CIS). For the thirteen one-dimensional regions, we have data from six post-electoral surveys conducted between 1986 and 2004. This gives us 78 region-year samples. For each of the two

\footnotetext{
5 Basque Country and Navarra belong to a so called "foral" regime of regional financing. These two regions retain a large part of the revenues from the major taxes. Contrary to the "foral" regime, regions belonging to a "common" regime-all the other 15 regions - are to a large extent financed through grants from the central government.

6 This is a free translation from Spanish to English. The exact questions are provided in Appendix.
} 
two-dimensional regions, we have data from five public opinion surveys conducted between 1987 and 2006. This gives us 10 region-year samples. In total we have 88 region-year samples in our data. See Appendix for more details about the surveys we use.

We drop all the respondents with missing self- or party placement on ideological dimensions. As a consequence, in one-dimensional regions we drop about onethird of the respondents, and in the two-dimensional regions, we drop about one half of the respondents. We also drop the respondents who perceive the scales in the reverse direction. By that we mean respondents who believe the PSOE to be more right-wing than the PP or the regional party to be more centralist than the PP. The share of respondents who perceive the scales in the reverse direction is always below 5\%, and we believe that most of these observations result from measurement errors. On average, we are left with 531 respondents per region in any given year. However, for some regions in some years we have few observations, in particular in Rioja, Cantabria and Baleares (see Table A.2 in Appendix). Voter distributions and the resulting proxies for loyal and swing voters are noisy when they are based on few observations.

We are not too concerned about the fact that some of the estimated voter distributions are noisy, because this noise cancels out in the regressions that we run. Note that in this paper, we are not primarily interested in the voter distribution in any particular region and period. Instead, we study the relationship between grants and swing voters that holds on average, across time and regions. We estimate this relationship consistently even if some individual observations are noisy, because the noise is independent across observations and thus cancels out. However, it would be worrying if our results crucially depended on the subset of the noisiest observations. To ensure that this is not the case, in the subsequent analysis we check the robustness of our empirical results to dropping the regions with the smallest number of observations. We find that our conclusions about distributive politics remain unaffected.

\section{Proxy for the Number of Loyal Voters}

To proxy for the number of loyal voters of the ruling party, we compute the share of respondents who report a smaller distance to the ruling party than to any other party. First, for each respondent we compute the Euclidean distance between respondent's ideal point and the perceived location of each party. Then we count the respondents for whom (i) the ruling party is the closest one and at the same time (ii) the distance to the second-closest party is at least $d \%$ larger than the distance to the ruling party. We experiment with a range of values of $d$ from 0 to $30 \%$ and find that the substantial results are robust to the choice of $d$ in this range.

\section{Proxy for the Number of Swing Voters: Share of Equidistant Voters}

Our first proxy for the number of swing voters is the share of respondents who report equal or approximately equal distances to the ruling party and to another party. We 
use the Euclidean distances computed before. Two distances are "similar" if they differ by at most $d \%$ and again we consider the range 0 to $30 \%$ for $d$. In the regions with three parties, we only count a respondent as a swing voter if her distance to the two similarly remote parties is smaller than her distance to the third party (otherwise she is not a swing voter of these two parties, but rather a loyal voter of that third party).

This proxy can be interpreted as a simple estimator of the density of the voters at the cutpoint between the ruling party and another party. The density is estimated by the height of the histogram. This estimator is consistent, but less precise than the kernel estimators of density. Therefore, our second proxy uses the kernel estimator.

\section{Proxy for the Number of Swing voters: Density at the Cutpoint}

Our second approach is to estimate the voter density at the cutpoint between the ruling party and another party. First, we rescale survey respondents' ideal points and party positions in order to put them in a common space. Second, we estimate the density of respondents' ideal points with kernel methods. Third, we evaluate this density at the cutpoint where a voter is equidistant to parties. The density evaluated at the cutpoint is our second proxy for the number of swing voters.

\section{Putting Parties and Voters in a Common Space}

We first map respondents' ideal points and party positions onto a common space. We do this in order to address the problem that different respondents interpret the endpoints and the intervals of the scale differently. For example, a moderate respondent might place herself (i.e., her ideal point) in the middle of the left-right scale, at 5, and she might place the PSOE and PP at the two extremes: the PSOE at 1 and PP at 10. In contrast, an extreme right-wing respondent might place herself to the right of both the PSOE and PP; for example, she would place herself at 8, the PSOE at 1 and $\mathrm{PP}$ at 2. Different interpretations of the scale imply that respondents' answers are not directly comparable. This problem is well known in the political science literature. Therefore, we follow this literature (see Aldrich and McKelvey (1977), Palfrey and Poole (1987), Poole (1998) and the website voteview.com) and map the respondents onto a common space using the Aldrich and McKelvey procedure. This procedure assumes that (i) a common ideological space exists and parties occupy fixed positions in this common space and (ii) due to subjective interpretations of the scale, respondents' reported positions are distorted by a respondent-specific linear transformation of the common space. Appendix B reports in detail how we apply the Aldrich and McKelvey procedure.

Once we have respondents and parties on a common scale, we estimate the density of voters' ideal points. 


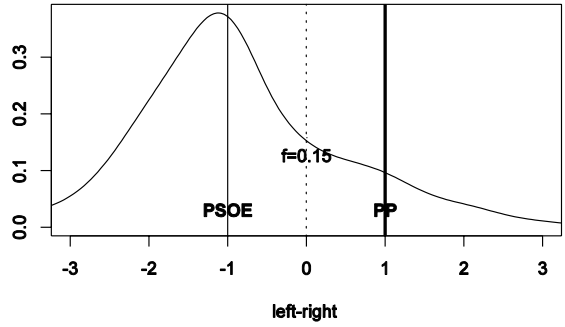

Castile-La Mancha, 1993

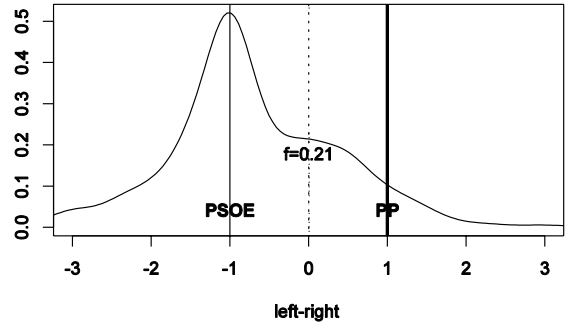

Valencian Community, 1993

Fig. 1 Densities of voter ideal points, locations of PSOE and PP and the density at the cutpoint: CastileLa Mancha and the Valencian Community in 1993

\section{Estimation of Voter Densities}

We estimate the density of voters' ideal points using the kernel density estimator following Wand and Jones (1995). We use the R package of Wand and Ripley (2010) with the default settings. The choice of bandwidth is the crucial decision in the kernel density estimation, since the bandwidth determines the smoothness of the density and number of modes. Our objective in the choice of bandwidth was to obtain densities whose shapes are reasonably smooth, but we used formal methods of bandwidth choice as much as possible. In the one-dimensional regions, we always choose the bandwidth using the direct plug-in method of Sheather and Jones (1991). In the two-dimensional regions, we fix the bandwidths at $0.25,0.25$, after experimenting with various bandwidths and automatic selection methods.

Let us highlight two observations based on inspecting the densities that we have obtained. First, these densities appear to be asymmetric and, in some cases, multimodal. This implies that proxies of swing or loyal voters based on voting data might be misleading. Consequently, to study hypotheses of distributive politics it is useful to use proxies based on surveys of ideological preferences. Second, these densities are quite stable over time. This implies that most of the variation in these densities happens as a result of changes of the ruling party. By comparison, the shifts in voter preferences are rather small and they account for little variation in the value of the density at the cutpoint. In Online Appendix, we provide further details and discussion of this point.

\section{Evaluating Density at the Cutpoint}

In one-dimensional regions, the density is univariate and the cutpoint is a single point. We illustrate our procedure in Fig. 1. This figure displays the densities of voters' ideal points and the party locations in Castile-La Mancha and in the Valencian Community in 1993. By construction, the PSOE is at -1 and the PP at 1 . In both regions, voter densities have clear modes at -1 , at the location of the PSOE. However, in the Valencian Community there are also a significant number of voters placed in the middle between the PSOE and the PP. The density at zero, which is our 


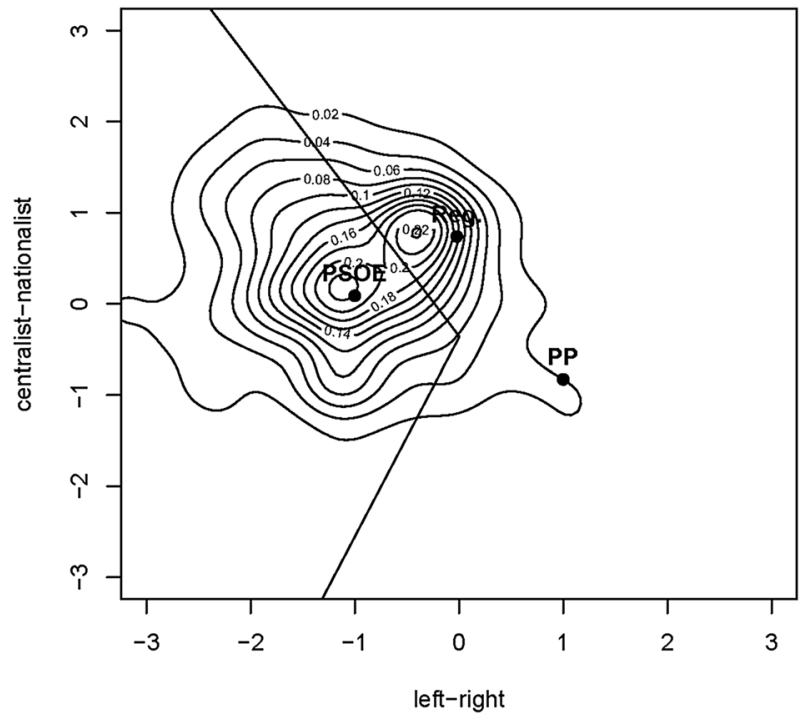

Fig. 2 Density of voters' ideal points in the two-dimensional ideological space, positions of the main parties and the lines on which voters are equidistant between PSOE and its competitors. Catalonia in 2006

proxy for the number of swing voters, is 0.15 in Castile-La Mancha and 0.21 in the Valencian Community.

In the two-dimensional regions, we proceed as follows. In a two-dimensional space, there are infinitely many equidistant points between any two parties and their collection is a line. In addition, in these regions we study competition between three major parties. What is important are the voters who are equidistant between the ruling party and the remaining two main parties. Therefore, the cutpoint in these cases consists of two line segments. Our swing voter proxy is the integral of the voter density (which is now bivariate) along the two line segments that separate the ruling party voters from the other parties' voters.

An illustration of this approach is provided in Fig. 2. This figure shows the bivariate density of voters' ideal points and the locations of the three major parties in Catalonia in 2006. The major regional party, the CIU is labeled "Reg." (for "Regional party"). The PSOE is the ruling party in 2006, and therefore, we are interested in those swing voters who might be attracted by the PSOE. These voters are located on the two line segments drawn in the picture. The integral of the voter density along the equidistant line segments equals 0.42 . As is clear from the picture, the majority of the swing voters are those who hesitate between the PSOE and CIU. In fact, the integral along the line between the PSOE and the CIU up to the intersection 
amounts to 0.35 and only the remaining 0.07 is accounted for by the integral along the line between the PSOE and the PP. ${ }^{7}$

Let us stress that the values of the densities at the cutpoint in two-dimensional regions and in one-dimensional regions are directly comparable. This is so, because the univariate density at the cutpoint that we compute in the one-dimensional regions is just a special case of the integral that we compute in the two-dimensional regions. To see this, think of all the regions, including one-dimensional regions, as having in fact two dimensions, and think of the values computed in one-dimensional regions as the integrals of two-dimensional densities along the equidistant line. The distinguishing feature of the one-dimensional regions is that in these regions there are only two major parties and these two parties do not differ along the centralist-nationalist dimension. This implies that in one-dimensional regions the cutpoint is a vertical line between the two parties. By the properties of probability densities, the integral along this vertical line is the value of the marginal density at the cutpoint in the left-right dimension. Thus, the evaluation of the density at the cutpoint in one-dimensional regions is just a special case of the computation that we perform in the two-dimensional regions.

\section{Empirical Analysis of the Determinants of Discretionary Grants}

In this section, we report the empirical results on the determinants of discretionary grants. We start by describing the regression equation that we estimate. Then we report the results of the OLS estimation of our baseline regression specification. Subsequently, we report the results obtained using different subsamples and alternative estimation techniques.

\section{The Regression We Estimate}

We estimate the following equation on annual regional data for the years 1987-2007:

$$
\begin{aligned}
\text { GRANTS }_{i t}= & \rho \text { GRANTS }_{i t-1}+\delta \text { Swing }_{i t-1}+\gamma \text { Loyal }_{i t-1} \\
& +\mu \text { Partisan alignment } \\
& +\alpha_{i t-1}+\beta \text { Region characteristics }_{i t}+\epsilon_{i t}
\end{aligned}
$$

\footnotetext{
7 We approximate the integral of the voter density along the equidistant line using Riemann sums. First, using Wand and Ripley (2010) software we compute the density at a 200x200 grid of equally spaced points between -7.5 and +7.5 in each dimension. Second, we compute the length of the line segment contained within each grid cell and we multiply this length by the height of the density at this grid cell. Third, we add up the obtained products of length and height for all grid cells crossed by the equidistant line. By the definition of the Riemann integral, this sum converges to the integral as the grid gets finer. We experimented with the grid size and we found the same results up to the second decimal point with grids $100 \times 100,200 \times 200$ and $1000 \times 1000$.
} 
where $i=1, \ldots, 15$ denotes regions and $t=1987,1988, \ldots, 2007$ denotes time.

\section{The Dependent Variable: Grants}

GRANTS $_{\text {it }}$ is the logarithm of per capita discretionary grants in region $i$ at time $t$. Discretionary grants are spent on different purposes which vary across time. In particular, discretionary grants are spent on (a) programs of retraining and job creation; (b) various social programs, e.g., the Plan of the Family Support, Gerontological Plan, support for old people with diseases; and (c) public investment in infrastructure. A small portion of the discretionary grants are also spent on agriculture and R\&D. Discretionary grants constituted $1.3 \%$ of general government expenditures on average in the studied period. They vary nontrivially over time: In an average region, their coefficient of variation over time is 0.4 in our sample.

The federal government allocates discretionary grants to regional governments. These grants are different from other grants in that there is no prescribed formula for their allocation. This discretionary nature makes these grants particularly suitable for testing theories of distributive politics.

The data on discretionary grants are only available at the regional level; they are not available for smaller administrative units. The data are annual and become available with a several years' delay. The data come from the database BADESPE of the Spanish Institute of Fiscal Studies (https://www.ief.es/BADESPE), and the variable name is "Subvenciones; Convenios inversión y Contratos-programa Estado."

We include lagged grants, GRANTS $_{\text {it- } 1}$, on the right-hand side in order to account for serial correlation in the allocation of grants. We always find this serial correlation to be significant and we think that it may result, e.g., from the presence of investments projects that are accomplished over several years. In some robustness exercises, we include also GRANTS it-2 $_{2}$.

\section{Proxies for the Number of Loyal and Swing Voters}

Swing $_{i t-1}$ and Loyal $_{i t-1}$ are proxies for the number of swing and loyal voters. Let us explain in detail how we introduce these proxies.

We make the following timing assumption. We assume that at the end of the year the central government observes the results from the most recent available survey of voter preferences or from the most recent general parliamentary election and then allocates grants for the following year across regions. Therefore, in the regression we use the lagged values of Swing and Loyal, as GRANTS for year $t$ are determined at the end of the previous year, $t-1$.

Swing and loyal voter proxies are party specific and they need to be computed for the party that was the ruling party at the end of the year $\mathrm{t}-1$. There were two changes in the ruling party during the studied period. The PSOE ruled since before 1987 until 1996, so in these years swing and loyal voter proxies are those for the PSOE. In 1996, the PP won the general parliamentary election. Therefore, from 1997 until 2004 swing and loyal voter proxies are those for the PP. In 2004 the PSOE came 
back to power. Therefore, from 2005 to 2007 swing and loyal voter proxies are those for the PSOE.

While the data on grants are annual, the surveys are only conducted once per four, five or sometimes more years (see Appendix A for the list of available surveys and their dates). Therefore, for the observations when there was no survey in period $t-1$ we use the swing and loyal proxies computed using the next most recent survey, provided that this survey is no more than 4 years old. If the most recent survey is more than 4 years old, we omit the observation from the estimation. ${ }^{8}$

We use two proxies for the number of swing voters based on the survey data: variables Swing density and Swing count. Variable Loyal count is our proxy for the number of loyal voters. We report the results with two versions of each of the Loyal count and Swing count variables: one version is computed with the threshold $d=30 \%$ and another version is computed with the threshold $d=0$.

How do proxies for swing and loyal voters based on the survey data correlate with the proxies based on voting data? There is a clear and positive correlation between our proxies of loyal voters from survey data and shares of pro-incumbent vote in general parliamentary elections at the regional level (variable Vote share for the ruling party). ${ }^{9}$ The correlation is 0.50 for the socialist party PSOE and 0.54 for the conservative party PP. This is a high and significant correlation and it is of similar magnitude as in Larcinese et al. (2012). However, those correlations are hardly overwhelming which indicates that ideological preferences are not simply another measure of voting behavior.

The correlation between the proxies of swing voters is more mixed. For the proxy for swing voters based on the voting data, we follow Solé-Olle (2013) and use vote margin of victory/defeat, defined as absolute difference between the incumbent's vote share and 45 percent (variable Incumbent's vote margin; the lower the vote margin, the larger is the number of swing "unattached" voters). The vote margin should be negatively correlated with the proxies based on the survey data, as the latter measure the number of swing voters. For swing voters of PP, correlation is in fact negative, but is only significant for Swing density measure and is not significant for the Swing count. The coefficient is equal to -0.17 for Swing density. For swing voters of PSOE, the correlation is positive and significant, and is equal to 0.30 .

The fact that correlation is not significant and has an opposite than expected sign in some years is not surprising. As it is well known and acknowledged in the literature (e.g., Dahlberg and Johansson 2002; Solé-Olle 2013), the incumbent's vote margin as a proxy of swing voters is only valid when the distribution of ideological preferences is symmetric and single peaked. However, in some regions we observe asymmetric and multimodal distributions of ideological preferences. For instance, this was the case in the 1989 election in Baleares region, where PP won many votes,

\footnotetext{
${ }^{8}$ For example, in Catalonia we have a survey in 1992 and then the next one only in 1999. Therefore, in the years 1993-1996 we use the loyal and swing proxies from the 1992 survey and we omit the observations for the years 1997-1999.

9 The voting data come from Ministerio del Interior, http://www.elecciones.mir.es/.
} 
the vote margin was quite high, but according to the survey data there are quite many swing voters in the region.

\section{Region Characteristics}

We include a number of region characteristics in order to control for equity and efficiency considerations in the distribution of discretionary grants. Note that discretionary grants are spent on many purposes and therefore it is difficult to find a single proxy that accounts for the need for discretionary grants. We include GDP per capita (in logs), population (in $\log$ s), the share of children up to 14 years old in the population (in percent), the unemployment rate (percent) and formula-based grants (as percent of regional GDP), all measured at the regional level. The data on the first four variables come from the Spanish Institute of Statistics (Instituto Nacional de Estadística). The data on formula-based grants come from database BADESPE of the Spanish Institute of Fiscal Studies, variable "Fondo de suficiencia (antes de 2002 PIE)." This is one of the main categories of grants and is designed to correct the mismatch between the needs of the region and its tax potential.

We expect the coefficient of GDP per capita to be negative according to equity considerations. The sign of the population coefficient depends on the strength of the two following factors. On the one hand, it is less costly to provide public goods in larger regions because of economies of scale. On the other hand, congestion results in deterioration of the quality of public goods so an additional transfer is required in populated regions (see Musgrave and Musgrave 1989). We include the share of children to account for the fact that grants are spent on various programs to support families with children. We include the unemployment rate to capture the fact that grants are spent on programs for the unemployed. Finally, the formula-based grants by definition capture the objective need for grants. All the regional controls are from the same period as the dependent variable because they are intended to capture regional needs in particular transfers and these can be reasonably predicted. Alternatively, one might argue that the decision makers simply look at the most recent data available. Therefore, we also estimated equations with lagged regional controls, but we do not report them because the results were very similar.

\section{Other Political Variable: Partisan Alignment}

We also control for partisan alignment of subnational governments (Arulampalam et al. 2009). We include in the regressions Partisan alingnment ${ }_{i t-1}$. This is a dummy that equals 1 if the incumbent party of the central government is also a member of a regional government. Partisan alignment dummy comes from (Simon-Cosano et al. 2013)..$^{10}$

\footnotetext{
10 As suggested by the literature (e.g., Carrozzi and Repetto 2019), we also included electoral turnout in the regressions and it turned out insignificant in various specifications. Following Simon-Cosano et al. (2013), we also included closeness of the election measured as absolute difference in the vote shares of the two main parties at the regional level and it proved insignificant as well. We do not report the results in the paper.
} 
Table 1 Determinants of discretionary grants, OLS, full sample, proxies of loyal and swing voters based on survey data

\begin{tabular}{|c|c|c|c|c|c|c|}
\hline Variable & (1) & (2) & (3) & (4) & $(5)$ & (6) \\
\hline Grants, lag 1 & $\begin{array}{l}0.55 * * * \\
(0.05)\end{array}$ & $\begin{array}{l}0.55^{* * * *} \\
(0.05)\end{array}$ & $\begin{array}{l}0.55 * * * \\
(0.05)\end{array}$ & $\begin{array}{l}0.55^{* * * *} \\
(0.05)\end{array}$ & $\begin{array}{l}0.55 * * * \\
(0.05)\end{array}$ & $\begin{array}{l}0.55^{* * * *} \\
(0.05)\end{array}$ \\
\hline \multicolumn{7}{|l|}{ Region characteristics: } \\
\hline GDP per capita & $\begin{array}{l}-0.60 \\
(0.49)\end{array}$ & $\begin{array}{l}-0.47 \\
(0.49)\end{array}$ & $\begin{array}{l}-0.60 \\
(0.49)\end{array}$ & $\begin{array}{l}-0.47 \\
(0.49)\end{array}$ & $\begin{array}{l}-0.76 \\
(0.54)\end{array}$ & $\begin{array}{l}-0.58 \\
(0.54)\end{array}$ \\
\hline Population & $\begin{array}{l}-0.92^{* *} \\
(0.38)\end{array}$ & $\begin{array}{l}-0.88^{* *} \\
(0.38)\end{array}$ & $\begin{array}{l}-0.92^{* *} \\
(0.38)\end{array}$ & $\begin{array}{l}-0.87^{* *} \\
(0.38)\end{array}$ & $\begin{array}{l}-1.04 * * \\
(0.44)\end{array}$ & $\begin{array}{l}-1.00^{* * *} \\
(0.43)\end{array}$ \\
\hline Share of children & & & & & $\begin{array}{l}-0.03 \\
(0.03)\end{array}$ & $\begin{array}{l}-0.02 \\
(0.03)\end{array}$ \\
\hline Unemployment rate & & & & & $\begin{array}{l}-0.00 \\
(0.01)\end{array}$ & $\begin{array}{l}0.00 \\
(0.01)\end{array}$ \\
\hline Formula-based grants & & & & & $\begin{array}{l}-0.79 \\
(1.37)\end{array}$ & $\begin{array}{l}-0.77 \\
(1.36)\end{array}$ \\
\hline \multicolumn{7}{|l|}{ Loyal hypothesis } \\
\hline Loyal count & $\begin{array}{l}0.48 * * \\
(0.23)\end{array}$ & $\begin{array}{l}0.60 * * \\
(0.24)\end{array}$ & $\begin{array}{l}0.46^{* * *} \\
(0.23)\end{array}$ & $\begin{array}{l}0.56^{* * *} \\
(0.23)\end{array}$ & $\begin{array}{l}0.48 * * \\
(0.24)\end{array}$ & $\begin{array}{l}0.59 * * \\
(0.25)\end{array}$ \\
\hline \multicolumn{7}{|l|}{ Swing hypothesis } \\
\hline Swing count & $\begin{array}{l}0.51 \\
(0.48)\end{array}$ & & $\begin{array}{l}0.47 \\
(0.56)\end{array}$ & & $\begin{array}{l}0.56 \\
(0.49)\end{array}$ & \\
\hline Swing density & & $\begin{array}{l}0.46^{*} \\
(0.27)\end{array}$ & & $\begin{array}{l}0.40 \\
(0.27)\end{array}$ & & $\begin{array}{l}0.45 \\
(0.27)\end{array}$ \\
\hline \multicolumn{7}{|l|}{ Other political variable } \\
\hline Partisan alignment & $\begin{array}{l}0.08 * * \\
(0.04)\end{array}$ & $\begin{array}{l}0.10 * * * \\
(0.04)\end{array}$ & $\begin{array}{l}0.09 * * \\
(0.04)\end{array}$ & $\begin{array}{l}0.10 * * * \\
(0.04)\end{array}$ & $\begin{array}{l}0.08 * * \\
(0.04)\end{array}$ & $\begin{array}{l}0.10 * * * \\
(0.04)\end{array}$ \\
\hline Observations & 307 & 307 & 307 & 307 & 307 & 307 \\
\hline$R$-squared & 0.88 & 0.88 & 0.88 & 0.88 & 0.88 & 0.88 \\
\hline Number of id & 15 & 15 & 15 & 15 & 15 & 15 \\
\hline
\end{tabular}

We control for regional fixed effects $\left(\alpha_{i}\right)$ and year dummies $\left(\tau_{t}\right)$ in all specifications. Here and in the following tables, the standard errors are in parentheses; $* * * p$-value $<0.01$, $* * p$-value $<0.05, * p$-value $<0.1$

Appendix A provides summary statistics of all the data that we used.

In all the regressions, we include year dummies $\left(\tau_{t}\right)$ in order to control for the fact that the total amount of grants changed over time. In all the OLS regressions, we control for regional fixed effects $\left(\alpha_{\mathrm{i}}\right),{ }^{11}$ while in all the GMM regressions we remove regional effects with an appropriate transformation.

\footnotetext{
11 The OLS estimation with fixed effects in a model with the lagged dependent variable might suffer from the dynamic panel bias (Nickell, 19811981). However, the dynamic panel bias is typical for short time-series. We have moderately large number of time periods ( $\mathrm{T}=21$ years). For a robustness check, we have estimated the baseline model using both models - with the lagged dependent variable and fixed effects-separately (Angrist and Pischke, 2009). We find broadly similar results using both models. We do not report results in the paper.
} 


\section{Results Obtained with the OLS Estimation on the Full Sample}

In this subsection, we estimate the above equation using ordinary least squares (OLS). (Later we discuss results obtained with other estimation techniques.)

Table 1 presents regressions estimated on the full sample with alternative sets of right-hand side variables. Columns (1)-(2) present our baseline specification. This specification includes lagged grants, two region characteristics, GDP per capita and population, loyal and swing proxies based on survey data and partisan alignment. Proxies Loyal count and Swing count are computed with $d=0.3$.

The results are consistent with the loyal voter hypothesis: regions with more loyal voters are getting higher grants per capita. The coefficients of Loyal count are significant at $5 \%$ level and positive both in the specification with Swing count and with Swing density. The magnitude of the effect of loyal voters is not negligible. ${ }^{12}$ Consider, for example, column (2). A one percentage point increase in the share of loyal voters in a region (as measured by Loyal count) increases grants per capita by $0.60 \%$. The standard deviation of the share of loyal voters is 14 percentage points, so, according to the results in column (2), a one standard deviation increase in the share of loyal voters in a region increases grants by $8 \%$.

The support for the swing voter hypothesis is weak. The coefficients of swing voter proxies have positive sign but they are not significant at $5 \%$ level. The coefficient of Swing density is significant at $10 \%$ level and the coefficient of Swing count is insignificant.

In addition, we find that the incumbent party favors regions where it is a member of the regional government. The Partisan alignment dummy is significant and positive in both specifications. This is consistent with findings for the Spanish case (Solé-Ollé and Sorribas-Navarro 2008; Curto-Grau et al. 2018), who also find that partisan alignment has a positive effect on the amount of grants received by subnational governments.

Among region characteristics, only Population is significant and negative in all specifications. A negative sign of Population implies that more populated regions are getting smaller transfers. This can be rationalized by economies of scale. GDP per capita is negative as expected in light of the equity considerations but is not significant.

Subsequent columns report various deviations from the baseline specification, one deviation at a time. In columns (3)-(4) we include proxies Loyal count and Swing count computed with $d=0$. The main effect of this change is that coefficient of Swing density ceases to be significant at $10 \%$ level. We verified that in also in other specifications, unreported for brevity, Swing density ceases to be significant when accompanied by Loyal count computed with $d=0$. In subsequent subsections, we report also other specification changes that yield an insignificant coefficient of

\footnotetext{
12 We cannot rule out, however, that the coefficients of loyal proxies are biased upward to the extent that the proxies based on survey data are endogenous. This problem is, however, likely to be limited. Please, also see the discussion on p. 5 in the Introduction.
} 
Table 2 Determinants of discretionary grants, OLS, full sample, proxies of loyal and swing voters based on voting data

\begin{tabular}{|c|c|c|c|c|c|c|}
\hline Variable & (1) & (2) & (3) & (4) & (5) & (6) \\
\hline Grants, lag 1 & $\begin{array}{l}0.55 * * * \\
(0.05)\end{array}$ & $\begin{array}{l}0.58 * * * \\
(0.05)\end{array}$ & $\begin{array}{l}0.54 * * * \\
(0.05)\end{array}$ & $\begin{array}{l}0.55^{* * *} * \\
(0.05)\end{array}$ & $\begin{array}{l}0.58 * * * \\
(0.05)\end{array}$ & $\begin{array}{l}0.54 * * * \\
(0.05)\end{array}$ \\
\hline \multicolumn{7}{|l|}{ Region characteristics: } \\
\hline GDP per capita & $\begin{array}{l}-0.74 \\
(0.48)\end{array}$ & $\begin{array}{l}-0.64 \\
(0.49)\end{array}$ & $\begin{array}{l}-0.72 \\
(0.48)\end{array}$ & $\begin{array}{l}-1.02 * \\
(0.54)\end{array}$ & $\begin{array}{l}-0.76 \\
(0.54)\end{array}$ & $\begin{array}{l}-0.99 * \\
(0.54)\end{array}$ \\
\hline Population & $\begin{array}{l}-1.02 * * * \\
(0.38)\end{array}$ & $\begin{array}{l}-0.89 * * \\
(0.38)\end{array}$ & $\begin{array}{l}-1.07^{* * * *} \\
(0.38)\end{array}$ & $\begin{array}{l}-1.28^{* * * *} \\
(0.43)\end{array}$ & $\begin{array}{l}-1.04 * * \\
(0.43)\end{array}$ & $\begin{array}{l}-1.31 \text { *** } \\
(0.43)\end{array}$ \\
\hline Share of young & & & & $\begin{array}{l}-0.01 \\
(0.03)\end{array}$ & $\begin{array}{l}-0.02 \\
(0.03)\end{array}$ & $\begin{array}{l}-0.01 \\
(0.03)\end{array}$ \\
\hline Unemployment rate & & & & $\begin{array}{l}-0.01 \\
(0.01)\end{array}$ & $\begin{array}{l}0.00 \\
(0.01)\end{array}$ & $\begin{array}{l}-0.01 \\
(0.01)\end{array}$ \\
\hline Formula-based grants & & & & $\begin{array}{l}-1.41 \\
(1.31)\end{array}$ & $\begin{array}{l}-1.12 \\
(1.33)\end{array}$ & $\begin{array}{l}-1.26 \\
(1.32)\end{array}$ \\
\hline \multicolumn{7}{|l|}{ Loyal hypothesis } \\
\hline Vote share for the ruling party & $\begin{array}{l}0.59 * * \\
(0.27)\end{array}$ & & $\begin{array}{l}0.73 * * \\
(0.29)\end{array}$ & $\begin{array}{l}0.67 * * \\
(0.29)\end{array}$ & & $\begin{array}{l}0.81 * * * \\
(0.31)\end{array}$ \\
\hline \multicolumn{7}{|l|}{ Swing hypothesis } \\
\hline Incumbent's vote margin & & $\begin{array}{l}0.12 \\
(0.39)\end{array}$ & $\begin{array}{l}0.53 \\
(0.42)\end{array}$ & & $\begin{array}{l}0.10 \\
(0.40)\end{array}$ & $\begin{array}{l}0.50 \\
(0.42)\end{array}$ \\
\hline \multicolumn{7}{|l|}{ Other political variable } \\
\hline Partisan alignment & $\begin{array}{l}0.09 * * \\
(0.03)\end{array}$ & $\begin{array}{l}0.10^{* * * *} \\
(0.03)\end{array}$ & $\begin{array}{l}0.08 * * \\
(0.04)\end{array}$ & $\begin{array}{l}0.08 * * \\
(0.04)\end{array}$ & $\begin{array}{l}0.10^{* * * *} \\
(0.03)\end{array}$ & $\begin{array}{l}0.07 * \\
(0.04)\end{array}$ \\
\hline Observations & 315 & 315 & 315 & 315 & 315 & 315 \\
\hline$R$-squared & 0.88 & 0.87 & 0.88 & 0.88 & 0.87 & 0.88 \\
\hline Number of id & 15 & 15 & 15 & 15 & 15 & 15 \\
\hline
\end{tabular}

We control for regional fixed effects $\left(\alpha_{i}\right)$ and year dummies $\left(\tau_{t}\right)$ in all specifications. Here and in the following tables, the standard errors are in parentheses; $* * * p$-value $<0.01, * * p$-value $<0.05, * p$-value $<0.1$

Swing density. Therefore, we conclude that the evidence in support of the swing hypothesis is not robust.

In columns (5)-(6), we include three additional region characteristics: the share of children, the unemployment rate and formula-based grants. Their coefficients are small and insignificant and their inclusion does not affect other coefficients much. We conclude that the allocation of discretionary grants across regions is unrelated to the share of children, the unemployment rate and formula-based grants.

Table 2 presents regressions estimated on the full sample with proxies of loyal and swing voters based on actual votes. Columns (1) and (4) test the loyal voter hypotheses, columns (2) and (5) test the swing voter hypotheses, and columns (3) and (6) test both hypotheses jointly.

The main conclusion from Table 2 is that the loyal hypothesis is confirmed. The coefficients of Vote share for the ruling party are positive and significant at $5 \%$ or $1 \%$, depending on the specification. When we compare the results with the proxies 
Table 3 Determinants of discretionary grants, OLS, sample without Rioja, Cantabria and Balearic Islands (1-2), and without Catalonia and Galicia (3-4)

\begin{tabular}{|c|c|c|c|c|}
\hline Variable & (1) & (2) & (3) & (4) \\
\hline Grants, lag 1 & $\begin{array}{l}0.59 * * * \\
(0.05)\end{array}$ & $\begin{array}{l}0.58 * * * \\
(0.05)\end{array}$ & $\begin{array}{l}0.54 * * * \\
(0.05)\end{array}$ & $\begin{array}{l}0.55^{* * * *} \\
(0.05)\end{array}$ \\
\hline \multicolumn{5}{|c|}{ Region characteristics: } \\
\hline GDP per capita & $\begin{array}{l}-0.50 \\
(0.49)\end{array}$ & $\begin{array}{l}-0.35 \\
(0.49)\end{array}$ & $\begin{array}{l}-0.54 \\
(0.51)\end{array}$ & $\begin{array}{l}-0.42 \\
(0.51)\end{array}$ \\
\hline Population & $\begin{array}{l}-0.82 * * \\
(0.39)\end{array}$ & $\begin{array}{l}-0.83 * * \\
(0.38)\end{array}$ & $\begin{array}{l}-1.05^{* * *} \\
(0.40)\end{array}$ & $\begin{array}{l}-1.00^{* *} \\
(0.41)\end{array}$ \\
\hline \multicolumn{5}{|l|}{ Loyal hypothesis } \\
\hline Loyal count & $\begin{array}{l}0.58 * * \\
(0.26)\end{array}$ & $\begin{array}{l}0.71 * * * \\
(0.26)\end{array}$ & $\begin{array}{l}0.57 * * \\
(0.25)\end{array}$ & $\begin{array}{l}0.63 * * \\
(0.26)\end{array}$ \\
\hline \multicolumn{5}{|l|}{ Swing hypothesis } \\
\hline Swing count & $\begin{array}{l}0.35 \\
(0.56)\end{array}$ & & $\begin{array}{l}0.54 \\
(0.57)\end{array}$ & \\
\hline Swing density & & $\begin{array}{l}0.59 * * \\
(0.26)\end{array}$ & & $\begin{array}{l}0.47 \\
(0.41)\end{array}$ \\
\hline \multicolumn{5}{|c|}{ Other political variable } \\
\hline Partisan alignment & $\begin{array}{l}0.06 \\
(0.04)\end{array}$ & $\begin{array}{l}0.07 * * \\
(0.04)\end{array}$ & $\begin{array}{l}0.09 * * \\
(0.04)\end{array}$ & $\begin{array}{l}0.10 * * * \\
(0.04)\end{array}$ \\
\hline Observations & 244 & 244 & 273 & 273 \\
\hline R-squared & 0.89 & 0.90 & 0.88 & 0.88 \\
\hline Number of id & 12 & 12 & 13 & 13 \\
\hline
\end{tabular}

We control for regional fixed effects $\left(\alpha_{i}\right)$ and year dummies $\left(\tau_{t}\right)$ in all specifications

based on the survey data, the coefficients for the loyal supporters are higher in several specifications with voting data. This confirms the positive bias in the estimates of the effect of core supporters for the incumbent party based on the voting data (Larcinese et al. 2012). Suppose people who are not core supporters of the socialist party PSOE actually voted for it in the past election. They will be counted as loyal voters of PSOE, although they are in fact swing voters. This results in a spurious correlation between loyal voters of PSOE and grants.

We do not find the support for the swing hypothesis. ${ }^{13}$ The coefficients are in fact positive and insignificant, with some coefficients close to zero. This is also in line with the simulations in Larcinese et al. (2012) and is the consequence of the endogeneity of proxies based on actual votes.

Next, we discuss the results obtained on the subset of regions and subset of years with proxies based on survey data.

\footnotetext{
13 The results in Table 2 are robust to inclusion of an alternative measure of Incumbent's vote margin, computed as the absolute difference between the incumbent's vote share and 50 percent of the votes in a region. We do not report the results in the paper.
} 
Table 4 Determinants of discretionary grants, OLS, samples with PSOE as ruling party (1-4) and with $\mathrm{PP}$ as ruling party (5-6)

\begin{tabular}{|c|c|c|c|c|c|c|}
\hline Variable & (1) & (2) & (3) & (4) & (5) & (6) \\
\hline Grants, lag 1 & $\begin{array}{l}0.31 * * * \\
(0.08)\end{array}$ & $\begin{array}{l}0.34 * * * \\
(0.08)\end{array}$ & $\begin{array}{l}0.52 * * * \\
(0.06)\end{array}$ & $\begin{array}{l}0.52 * * * \\
(0.06)\end{array}$ & $\begin{array}{l}0.23 * * \\
(0.09)\end{array}$ & $\begin{array}{l}0.22 * * \\
(0.09)\end{array}$ \\
\hline \multicolumn{7}{|c|}{ Region characteristics: } \\
\hline GDP per capita & $\begin{array}{l}0.02 \\
(0.95)\end{array}$ & $\begin{array}{l}0.89 \\
(0.91)\end{array}$ & $\begin{array}{l}0.30 \\
(0.64)\end{array}$ & $\begin{array}{l}0.31 \\
(0.64)\end{array}$ & $\begin{array}{l}-1.92 \\
(1.69)\end{array}$ & $\begin{array}{l}-2.36 \\
(1.71)\end{array}$ \\
\hline Population & $\begin{array}{l}-0.62 \\
(1.57)\end{array}$ & $\begin{array}{l}0.35 \\
(1.55)\end{array}$ & $\begin{array}{l}-0.30 \\
(0.48)\end{array}$ & $\begin{array}{l}-0.26 \\
(0.48)\end{array}$ & $\begin{array}{l}-2.66^{*} \\
(1.42)\end{array}$ & $\begin{array}{l}-2.69 * * \\
(1.35)\end{array}$ \\
\hline \multicolumn{7}{|l|}{ Loyal hypothesis } \\
\hline Loyal count & $\begin{array}{l}1.70 * * * \\
(0.62)\end{array}$ & $\begin{array}{l}1.14 * * \\
(0.56)\end{array}$ & $\begin{array}{l}0.53^{*} \\
(0.32)\end{array}$ & $\begin{array}{l}0.59 * \\
(0.32)\end{array}$ & $\begin{array}{l}1.15^{*} \\
(0.68)\end{array}$ & $\begin{array}{l}0.92 \\
(0.71)\end{array}$ \\
\hline \multicolumn{7}{|l|}{ Swing hypothesis } \\
\hline Swing count & $\begin{array}{l}2.44^{*} \\
(1.30)\end{array}$ & & $\begin{array}{l}0.35 \\
(0.75)\end{array}$ & & $\begin{array}{l}-0.21 \\
(1.68)\end{array}$ & \\
\hline Swing density & & $\begin{array}{l}1.14 * \\
(0.67)\end{array}$ & & $\begin{array}{l}0.44 \\
(0.49)\end{array}$ & & $\begin{array}{l}-1.13 \\
(1.04)\end{array}$ \\
\hline \multicolumn{7}{|c|}{ Other political variable } \\
\hline Partisan alignment & $\begin{array}{l}0.17 * * \\
(0.08)\end{array}$ & $\begin{array}{l}0.18 * * \\
(0.09)\end{array}$ & $\begin{array}{l}0.11^{*} \\
(0.06)\end{array}$ & $\begin{array}{l}0.13^{* *} \\
(0.06)\end{array}$ & $\begin{array}{l}-0.08 \\
(0.09)\end{array}$ & $\begin{array}{l}-0.07 \\
(0.09)\end{array}$ \\
\hline Observations & 147 & 147 & 191 & 191 & 116 & 116 \\
\hline$R$-squared & 0.65 & 0.65 & 0.90 & 0.90 & 0.75 & 0.75 \\
\hline Number of id & 15 & 15 & 15 & 15 & 15 & 15 \\
\hline
\end{tabular}

We control for regional fixed effects $\left(\alpha_{i}\right)$ and year dummies $\left(\tau_{t}\right)$ in all specifications

\section{Results Obtained with the OLS Estimation on Subsets of Regions}

In Table 3, we report the results obtained in subsets of regions. First, we check the robustness of the loyal voter result to dropping the regions where the loyal and swing voter proxies are the noisiest due to the smallest numbers of survey respondents. We find that the results are robust. We have the smallest number of survey respondents in La Rioja, Cantabria and the Balearic Islands. Columns (1) and (2) report the regression results obtained without these regions. We find that the results remain unchanged. The coefficients of Loyal count are significant at $1 \%$ or $5 \%$ level and positive in all specifications. All the coefficients are similar to those obtained on the full sample. We conclude that our results are not driven by the noisiest measurements of the loyal and swing proxies.

Second, we check the robustness of the results to excluding Catalonia and Galicia from the sample. Columns (3) and (4) report these results. We find that the support for the loyal voter hypothesis is robust to omitting Catalonia and Galicia. The coefficients of Loyal count are similar as in the full sample and significant at 5\% level. By contrast, the coefficients of both swing voter proxies are insignificant when Catalonia and Galicia are excluded from the sample. We excluded the two-dimensional regions, Catalonia and Galicia, because, as discussed earlier, in these regions the variation in the Swing density is larger than in other regions and we wondered how 
much these two regions drive the results. It turns out that the significance of Swing density is sensitive to omitting Catalonia and Galicia, while the significance of Loyal count is not. To sum up, we find that our previous conclusions are robust to omitting relevant subsets of regions.

The evidence for the partisan alignment hypothesis at the level of regions is robust in all but one specification (column 1). Next, we further check the robustness of partisan alignment hypothesis by studying the subset of years.

\section{Results Obtained with the OLS Estimation on Subsets of Years}

Table 4 reports the results for three subsets of years: the period 1987-1996, i.e., the first period when the PSOE was the ruling party (columns 1-2), the periods 1987-1996 and 2005-2007, i.e., all the years in our sample when the PSOE was the ruling party (columns 3-4), and the period 1997-2004, when the PP was the ruling party (columns 5-6). We find some support for the loyal hypothesis in all these subsets of years, although in the smallest subset, the one where PP was the ruling party, the results are not always statistically significant. We also find some interesting variation in the determinants of discretionary grants across these subsets of years.

In both subsamples when the PSOE was the ruling party the coefficient of Loyal count is significant at either $1 \%$ or $5 \%$. In the subsample, when the PP was the ruling party the coefficient of Loyal count is only significant at $10 \%$ in only one of the specifications, when included together with the Swing count variable. However, the coefficient of Loyal count is quite large in the PP subsample (1.15 and 0.92), depending on the specification), larger than in the full sample. The lack of significance may be a consequence of the small number of observations in this subsample.

The swing voter hypothesis is confirmed robustly neither in the PSOE samples nor in the PP sample. The swing voter proxies are significant at $10 \%$ in only one of the samples, namely in the first period of the PSOE rule. We deem this evidence as not robust enough.

The evidence for the partisan alignment hypothesis depends on the studied subsample. The Partisan alignment dummy is positive and significant in the PSOE years, but become negative and insignificant during the PP rule. We conclude that partisan alignment hypothesis is only confirmed during the PSOE years.

Interestingly, the determinants of discretionary grants vary quite a lot across the studied subperiods. In the PP years there is a systematic relationship between region characteristics and grants: poorer and less populous regions received larger grants. No relation between region characteristics and grants seems to be present in the PSOE years. In the PP sample, the coefficient of GDP per capita is negative, as required by equity considerations, although not significant. In the PSOE samples, the coefficient of GDP per capita is very small and actually positive. The coefficient of Population is negative in all samples, but in the PP sample it is larger in absolute value and significant.

To summarize, when looking at subsamples we also find evidence that regions with more voters loyal to the ruling party received more grants per capita, although this finding is not statistically significant in the smallest subsample, the one when 
the PP was in the ruling party. We also find the confirmation for the partisan alignment hypothesis during the PSOE years.

\section{A Summary of Other Robustness Checks}

We have also verified that our results are robust to using Arellano-Bondtype dynamic panel estimators instead of the OLS. Our panel regressions are dynamic - they include the lag of the dependent variable-and it is important to use Arellano-Bond-type dynamic panel estimators (Arellano and Bond 1991; Arellano and Bover 1995) when the time dimension of the panel is short. However, our panel has a relatively large number of time periods (at most $T=21$ years, although some observations are missing in some regions). Monte Carlo results of Judson and Owen (1999) suggest that at our sample size the OLS estimation may be the optimal approach. The results with the Arellano-Bond-type estimators yield similar lessons and are provided in Online Appendix.

\section{Conclusion}

We studied the determinants of geographic allocation of discretionary grants in Spain. Among the potential determinants we included proxies for the number of loyal and swing voters of the ruling party. We computed these proxies from public opinion surveys. Our proxies are preferable, on theoretical grounds, to the commonly used proxies based on voting data. In the construction of our proxies, we took into account the specifics of Spanish regions: ideological two-dimensionality and multiparty competition in some of the regions.

The key findings are as follows. First, we find support for the Cox and McCubbins (1986) hypothesis that parties distribute transfers to regions with many loyal voters. The effect of loyal voters is statistically significant and sizeable, given the level of aggregation in our data. For example, according to our baseline specification an increase of our loyal voter proxy by one standard deviation is associated with an $8 \%$ increase in per capita grants. Second, we find evidence that grants were biased in favor of the regions where there is partisan alignment between the central and regional layers of government during the PSOE rule.

\section{Appendix A: Data}

We use the following surveys conducted by the CIS (Centro de Investigaciones Sociológicas):

See Table 5 . 
Table 5 Surveys used for the estimation of the shares of swing and loyal voters

\begin{tabular}{llll}
\hline Survey number & Year & Survey title & Regions covered \\
\hline 1542 & 1986 & Post-electoral survey, general election & All \\
1720 & 1987 & Public opinion survey & Galicia \\
1750 & 1988 & Post-electoral survey, regional election & Catalonia \\
1842 & 1989 & Post-electoral survey, general election & All \\
2033 & 1992 & Public opinion survey & Catalonia \\
2036 & 1992 & Public opinion survey & Galicia \\
2061 & 1993 & Post-electoral survey, general election & All \\
2070 & 1993 & Post-electoral survey, regional election & Galicia \\
2210 & 1996 & Post-electoral survey, general election & All \\
2263 & 1997 & Post-electoral survey, regional election & Galicia \\
2374 & 1999 & Post-electoral survey, regional election & Catalonia \\
2384 & 2000 & Post-electoral survey, general election & All \\
2546 & 2003 & Post-electoral survey, regional election & Catalonia \\
2559 & 2004 & Post-electoral survey, general election & All \\
2611 & 2005 & Post-electoral survey, regional election & Galicia \\
2660 & 2006 & Post-electoral survey, regional election & Catalonia \\
\hline
\end{tabular}

Surveys are accessed at http://www.cis.es/cis/opencm/ES/2_bancodatos/estudios/tematico.jsp

The surveys that cover all regions (such as 1542,1842 etc.) do not include the questions on the national/regional dimension. Therefore, for Galicia and Catalonia we do not use these surveys, and instead, we use the surveys specific for Galicia and Catalonia (such as 1720, 1750 etc.).

Below we paste examples of the survey questions that we use. The exact wording differs only insignificantly across years.

Questions about the left-right dimension:

Cuando se habla de politica se utilizan normalmente las expresiones izquierda y derecha. En esta tarjeta hay una serie de casillas que van de izquierda a derecha. ?En que casilla se colocaria Ud.?

?Y en que casilla de esa misma escala colocaria Ud. A cada uno de los siguientes partidos?"

Questions about the national/regional dimension:

En relacion con el sentimiento nacionalista, ?podria decirme por favor, donde se colocaria Ud. en una escala de 1 a 10 en la cual el 1 significa el minimo grado de nacionalismo catalan y el 10 el maximo grado de nacionalismo catalan?

$Y$, utilizando esa misma escala de nacionalismo catalan, ?donde situaria Ud. A cada uno de los siguientes partido o coaliciones?

The following table reports the final number of respondents in year-region samples:

See Tables 6 and 7. 
Table 6 Number of respondents in year-region samples after dropping missing values and respondents with reversed ideological scale

\begin{tabular}{lrrc}
\hline Region & Average & Minimum & Maximum \\
\hline Andalusia & 526 & 274 & 755 \\
Aragon & 141 & 45 & 332 \\
Principality of Asturias & 92 & 41 & 151 \\
Balearic Islands & 85 & 29 & 215 \\
Canary Islands & 131 & 45 & 316 \\
Cantabria & 61 & 17 & 185 \\
Castile and León & 241 & 119 & 406 \\
Castile-La Mancha & 176 & 63 & 391 \\
Catalonia & 1197 & 873 & 1717 \\
Extremadura & 129 & 58 & 362 \\
Galicia & 1002 & 714 & 1347 \\
Community of Madrid & 449 & 206 & 523 \\
Region of Murcia & 88 & 39 & 224 \\
La Rioja & 53 & 17 & 211 \\
Valencian Community & 348 & 146 & 426 \\
\hline
\end{tabular}

Table 7 Summary statistics of the variables used in the regressions

\begin{tabular}{llllll}
\hline Variable & Obs & Mean & Std. dev. & Min & Max \\
\hline Grants per capita, euros & 330 & 72,12 & 48,62 & 13,28 & 257,24 \\
$\begin{array}{l}\text { Economic and demographic controls } \\
\text { GDP per capita, euros }\end{array}$ & 330 & 12548 & 5795 & 3294 & 30513 \\
$\begin{array}{l}\text { Population, thousand } \\
\text { Share of children (up to 14 years) }\end{array}$ & 330 & 2515 & 2136 & 260 & 7989 \\
Unemployment rate & 330 & 17 & 3 & 10 & 26 \\
$\begin{array}{l}\text { Proxies from survey data Loyal voter hypothesis } \\
\text { Loyal count }\end{array}$ & 88 & 0.32 & 0.14 & 0.04 & 0.59 \\
$\begin{array}{l}\text { Swing voter hypothesis } \\
\text { Swing count }\end{array}$ & 88 & 0.08 & 0.05 & 0 & 0.20 \\
$\begin{array}{l}\text { Swing density } \\
\text { Proxies from voting data }\end{array}$ & 88 & 0.23 & 0.08 & 0.05 & 0.43 \\
Vote share for the ruling party & 90 & 0.43 & 0.07 & 0.18 & 0.60 \\
Incumbent's vote margin & 90 & 0.07 & 0.05 & 0.00 & 0.27 \\
Other political controls & & & & & \\
Partisan alignment & 330 & 0.50 & 0.50 & 0 & 1 \\
\hline
\end{tabular}




\section{Appendix B: Mapping Parties and Voters Onto a Common Space}

In this appendix, we explain in detail how we rescale voters' ideal points and party positions so as to put them in a common space. We proceed in up to four steps, depending on the type of the region. The first two steps are common to all the regions. The last two steps apply only to the two-dimensional regions.

(1) Step 1: We ensure that responses about the left-right dimension are comparable across individuals within a given region. To this end, we rescale all the responses with the Aldrich and McKelvey (1977) procedure implemented in Poole et al. (2011). This procedure identifies and undoes the respondent-specific linear transformations of the common space. In a nutshell, this procedure assumes that responses may be contaminated by a random measurement error, and finds the respondent-specific linear transformations that deliver in the common space the best fit, in a least-squares sense, between the party positions and the respondents' perceptions of them (Aldrich and McKelvey 1977, p.114). ${ }^{14}$

(2) Step 2: We ensure that these scaled responses on the left-right dimension are comparable across regions. The PSOE and PP are countrywide parties and they communicate with the public largely via countrywide mass media, so we assume that their respective positions on the left-right dimension are the same across regions. Note that each regional common space recovered in the previous step via the Aldrich-McKelvey procedure is only identified up to an arbitrary linear transformation. Therefore, in step 2 we pin down this linear transformation by requiring that in each region the PSOE has a score of -1 and PP a score of 1 on the left-right dimension.

In the two-dimensional regions, we perform two additional steps.

(3) Step 3: We ensure that the responses about the centralist-nationalist dimension are comparable across individuals within each two-dimensional region, rescaling them with the Aldrich and McKelvey (1977) procedure as described in Step 1.

(4) Step 4: We rescale the centralist-nationalist dimension appropriately relative to the left-right dimension, in order to obtain a two-dimensional common space that is as relevant as possible for the voting decision. Specifically, in each region we rescale the centralist-nationalist dimension so that in this region the variance of respondents' ideal points on the centralist-nationalist dimension is the same as the variance of respondents' ideal points on the left-right dimension. We follow Aldrich and McKelvey (1977), who advocate this way of rescaling. Their logic is that the variance of respondents' ideal points on each dimension is a good proxy for the relative dispersion of party positions. They show that

\footnotetext{
${ }^{14}$ The scaling problem is nontrivial when there are more than two parties. With two parties it is trivial to find for each respondent a linear transformation that produces a common location of two parties. But when a third party is present, its location after this transformation will typically not coincide across individuals. Aldrich and McKelvey ascribe the disagreements across individuals about party positions to measurement error and their transformation is the one that implies the smallest measurement error.
} 
their way of rescaling significantly helps forecast the actual vote and yields better forecasts than alternative ways of rescaling.

Supplementary Information The online version contains supplementary material available at https://doi. org/10.1057/s41294-022-00186-3.

Acknowledgements I thank Robin Hogarth, Teresa Garcia-Milá, Marek Jarocinski, Josep Colomer, Ekaterina Zhuravskaya, Nuria Bosch, two referees and seminar participants at the Universitat Pompeu Fabra, EBS Universität für Wirtschaft und Recht, CASE-Center for Social and Economics Research, Aix-Marseille School of Economics for useful discussions and help. I thank Santiago Lago Peñas for making available the data on partisan alignment. Finally, I acknowledge the financial support from the Spanish Ministry of Science and Technology (FPI Scholarship).

Funding Open Access funding enabled and organized by Projekt DEAL.

Open Access This article is licensed under a Creative Commons Attribution 4.0 International License, which permits use, sharing, adaptation, distribution and reproduction in any medium or format, as long as you give appropriate credit to the original author(s) and the source, provide a link to the Creative Commons licence, and indicate if changes were made. The images or other third party material in this article are included in the article's Creative Commons licence, unless indicated otherwise in a credit line to the material. If material is not included in the article's Creative Commons licence and your intended use is not permitted by statutory regulation or exceeds the permitted use, you will need to obtain permission directly from the copyright holder. To view a copy of this licence, visit http://creativecommons.org/licen ses/by/4.0/.

\section{References}

Aldrich, H., and R.D. McKelvey. 1977. A method of scaling with applications to the 1968 and 1972 presidential elections. The American Political Science Review 71(1): 111-130.

Angrist, J.D., and J. Pischke. 2009. Mostly harmless econometrics. Princeton University Press.

Arulampalam, W., S. Dasgupta, A. Dhillon, and D. Bhaskar. 2009. Electoral goals and center-state transfers: A theoretical model and empirical evidence from India. Journal of Development Economics 88(1): 103-119.

Arellano, M., and S. Bond. 1991. Some tests of specification for panel data: Monte Carlo evidence and an application to employment equation. The Review of Economic Studies 58: 277-297.

Arellano, M., and O. Bover. 1995. Another look at the instrumental variables estimation of error-components models. Journal of Econometrics 68: 29-51.

Carrozzi, F., and L. Repetto. 2019. Distributive politics inside the city? The political economy of Spain's Plan E. Regional Science and Urban Economics 75: 85-106.

Case, A. 2001. Election goals and income redistribution: Recent evidence from Albania. European Economic Review 45: 405-423.

Castells, A., and A. Solé-Ollé. 2005. The regional allocation of infrastructure investment: the role of equity, efficiency and political factors. European Economic Review 49(5): 1165-1205.

Colomer, J., 2003. Political institutions. Oxford U.P.

Cox, G., and M. McCubbins. 1986. Electoral politics as a redistributive game. Journal of Politics 48: 370-389.

Curto-Grau, M., A. Solé-Ollé, and P. Sorribas-Navarro. 2018. Does electoral competition curb party favoritism? American Economic Journal: Applied Economics 10(4): 378-407.

Dahlberg, M., and E. Johansson. 2002. On the vote-purchasing behavior of incumbent governments. American Political Science Review 96(1): 27-40.

Dixit, A., and J. Londregan. 1995. Redistributive politics and economics efficiency. American Political Science Review 89: 856-866. 
Dixit, A., and J. Londregan. 1996. The determinants of success of special interests in redistributive politics. Journal of Politics 58(4): 1132-1155.

Jarocinska, E. 2010. Intergovernmental grants in Russia: Vote-buying or bargaining power of regions? Economics of Transition 18(2): 405-427.

Johansson, E. 2003. Intergovernmental grants as a tactical instrument: Empirical evidence from Swedish municipalities. Journal of Public Economics 87(5-6): 883-915.

Judson, R.A., and A.L. Owen. 1999. Estimating dynamic panel models: A practical guide for macroeconomists. Economics Letters 65: 9-15.

Larcinese, V., L. Rizzo, and C. Testa. 2006. Allocating the US Federal budget to the states: the impact of the President. Journal of Politics 68: 447-456.

Larcinese, V., J.M. Snyder, and C. Testa. 2012. Testing models of distributive politics using exit polls to measure voters preferences and partisanship. British Journal of Political Science, Available on CJO. https://doi.org/10.1017/S0007123412000245.

Levitt, S.D., and J.M. Potterba. 1999. Congressional distributive politics and state economic performance. Public Choice 99(1-2): 185-216.

Levitt, S.D., and J.M. Snyder Jr. 1995. Political parties and the distribution of federal outlays. American Journal of Political Science 39: 958-980.

Lindbeck, A., and J.W. Weibull. 1987. Balanced-budget redistribution as the outcome of political competition. Public Choice 52: 273-297.

Maravall, J.M., and A. Przeworski. 2001. Political reactions to the economy: the Spanish experience. In Political support for market reform in new democracies, ed. S.C. Stokes, 35-76. Cambridge University Press.

Musgrave, R.A., and P.B. Musgrave. 1989. Public finance in theory and practice. New York: McGraw-Hill.

Nickell, S. 1981. Biases in dynamic models with fixed effects. Econometrica 49(6): 1417-1426.

Palfrey, T.R., and K.T. Poole. 1987. The relationship between information, ideology, and voting behavior. American Journal of Political Science 31(3): 511-530.

Poole, K.T. 1998. Recovering a basic space from a set of issue scales. American Journal of Political Science 42(3): 954-993.

Poole, K. T., Rosenthal, H., Lewis, J., Lo, J. and R. Carrol, 2011. Basicspace: A package to recover a basic space from issue scales. R package version 0.02. http://CRAN.R-project.org/package=basic space

Sánchez-Cuenca, I. 2007. How can governments be accountable if voters vote ideologically? In Controlling governments: Voters, institutions and accountability, ed. J.M. Maravall and I. Sánchez-Cuenca, 45-81. Cambridge University Press.

Schady, N.R. 2000. The political economy of expenditures by the peruvian social fund (FONCODES), 1991-1995. The American Political Science Review 94(2): 289-304.

Sheather, S.J., and M.C. Jones. 1991. A reliable data-based bandwidth selection method for kernel density estimation. Journal of the Royal Statistical Society, Series B 53: 683-690.

Simon-Cosano P., Lago-Peñas S. and Vaquero A. (2013). "On the political determinants of intergovernmental grants in decentralized countries: The case of Spain." Publius: The Journal of Federalism, 44: $135-156$

Snyder, J.M. 1989. Election goal and the allocation of campaign resources. Econometrica 57(3): 637-660.

Snyder, J.M. 1990. Resource allocation in multiparty elections. American Journal of Political Science 34(1): 59-73.

Solé-Ollé, A., and P. Sorribas-Navarro. 2008. The effects of partisan alignment on the allocation of intergovernmental transfers. Differences-in-differences estimates for Spain. Journal of Public Economics 92: 2302-2319.

Solé-Ollé, A. 2013. Inter-regional redistribution through infrastructure investment: Tactical or programmatic? Public Choice 156(1-2): 229-252.

Strömberg, D. 2004. Radio's impact on public spending. The Quarterly Journal of Economics, 119(1), 189-221.

Testa, C., V. Larcinse, and L. Rizzo. 2006. Allocating the U.S. federal budget to the states: The impact of the president. The Journal of Politics 68(2): 447-456.

Veiga, L., and M. Pinho. 2007. The political economy of intergovernmental grants: Evidence from a maturing democracy. Public Choice 133(3): 457-477.

Wand, M.P., and M.C. Jones. 1995. Kernel smoothing. London: Chapman and Hall. 
Wand, M. and B. Ripley, 2010. KernSmooth: Functions for kernel smoothing for Wand \& Jones (1995). R package version 2.23-4. http://CRAN.R-project.org/package=KernSmooth

Wright, G., 1974. The political economy of New Deal spending: an econometric analysis. The Review of Economics and Statistics 56(1): 30-38.

Publisher's Note Springer Nature remains neutral with regard to jurisdictional claims in published maps and institutional affiliations. 